\title{
Exploration of the Sarfartôq carbonatite complex, southern West Greenland
}

\author{
K. Secher
}

\begin{abstract}
Frederic H. Lahee (1952)

Carbonatite was emplaced in two stages at $c .600 \mathrm{Ma}$ in the border between the Archaean craton and the Nagssugtoqidian mobile belt. During and after emplacement hydrothermal activity gave rise to fenitisation and alteration with increased contents of $\mathrm{Nb}$ and REE adjacent to the igneous core.
\end{abstract}

'Directly and indirectly field geology embraces many phases of both surface geology and subsurface geology'

\section{Introduction}

At the end of the 1960s no carbonatite complexes were known from Greenland except for the Proterozoic Gardar occurrences of Grønnedal-Ika (Emeleus, 1964) and Qagssiarssuk (Stewart, 1970). Today an extensive and complex suite of alkaline igneous rocks of carbonatitic and kimberlitic affinity is known to occur in the basement rocks of southern West Greenland, stretching from Ivigtut to north of Holsteinsborg (for summary see Larsen et al., 1983). This rock suite includes one minor and two major carbonatite intrusions in the Sukkertoppen - Søndre Strømfjord region (fig. 1).

In spite of the recent discovery of these carbonatite intrusions they are now quite well known, thanks to a wealth of data collected by a combination of geological, geophysical and geochemical methods. This is especially the case for the Sarfartôq carbonatite complex where all the investigations have been carried out by GGU. The following is a record of the many-sided process by which, from reports of a basement area with scattered carbonatitic dykes and marble-like rocks (Escher \& Watterson, 1973; J. C. Escher, personal communication, 1975), there emerged in the course of a few years a detailed picture of the $c .100 \mathrm{~km}^{2}$ Sarfartôq carbonatite complex with its high contents of phosphorus, niobium, uranium and rare earth elements.

\section{Discovery of the carbonatite complexes in West Greenland}

The Palaeozoic Qaqarssuk complex was found by Kryolitselskabet Øresund A/S in 1969. It was incorporated in GGU's activities in 1977 (Kunzendorf \& Secher, in press; Knudsen \& Secher, 1984; Knudsen, 1985). Investigation of the economic potential of the complex was carried out by Kryolitselskabet Øresund A/S. Prospecting was still in progress in 1975 (Nielsen, 1976), but exploration was terminated in 1977, the deposit apparently being too limited to be of economic interest. Another result of the Kryolitselskabet Øresund activity was dis- 


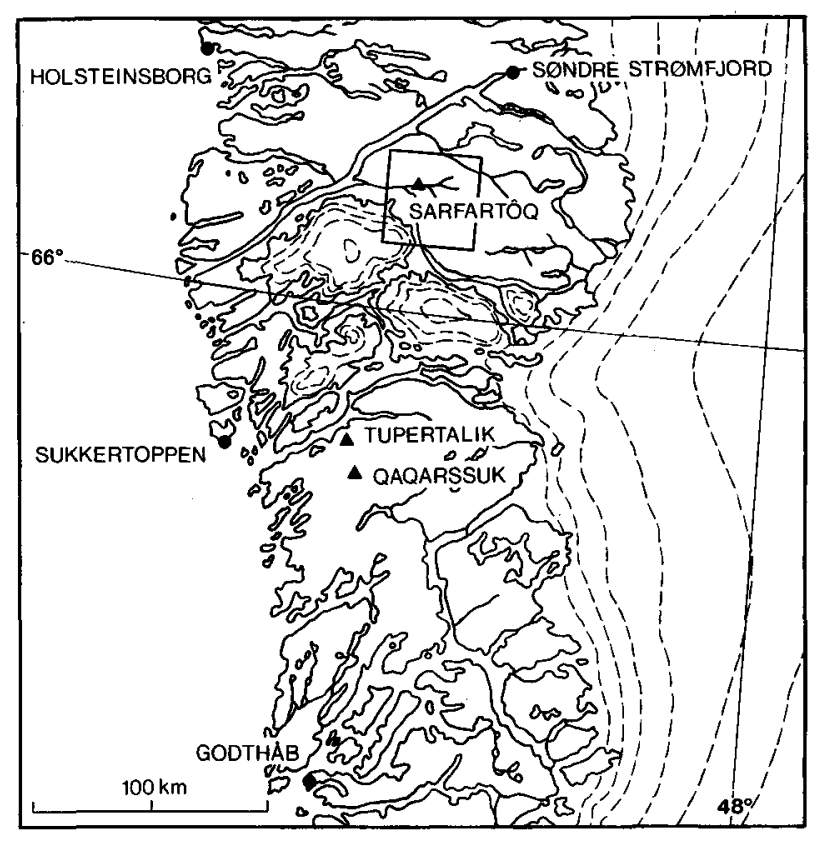

Fig. 1. Location of the Sarfartôq $(600 \mathrm{Ma})$, Tupertalik $(2650 \mathrm{Ma})$ and Qaqarssuk (175 Ma) carbonatite intrusions in West Greenland. The area covered by fig. 2 is outlined.

covery of the very small Tupertalik carbonatite intrusion in 1971 . This was later mapped and described by GGU (Larsen \& Pedersen, 1982).

The Sarfartôq carbonatite complex was discovered in 1975 as a result of a regional airborne radiometric survey carried out by GGU in 1975-76 (Secher, 1976, 1977), using instrumentation developed at the Risø National Laboratory (Christiansen, 1973). Its existence was first suggested by the anomalous reaction in the gross channel of the gamma spectrometer used during the survey in 1975 . What was expected to be a radioelement anomaly developed along the Nagssugtoqidian boundary was considered, after closer examination of the rocks from the aircraft, and after re-flying of the routes several times, to be an unusual type of anomaly related to some kind of igneous rock. From channel switches during the flight it was found that $U$ and $T h$ alternated as anomalous elements although Th was the most frequent. A short helicopter stop later in the season revealed the presence of carbonate rocks, which after analysis clearly showed a carbonatitic pedigree (Secher, 1976).

\section{Investigation strategy and methods}

A detailed examination of the Sarfartôq complex was carried out in the years 1977-79 and 1981, aimed at detailed mapping of the carbonatite (an area of $c .100 \mathrm{~km}^{2}$ ) and an evaluation of its economic potential. Local conditions of topography, exposure and mineral distribution made the use of a single method of mapping unsatisfactory, and a combination of geological methods had to be employed. The choice of methods was guided by the physical and chemical properties of the different rock units, and a combination of geomagnetic, radiometric and geochemical methods with conventional field geological observations was found to be 


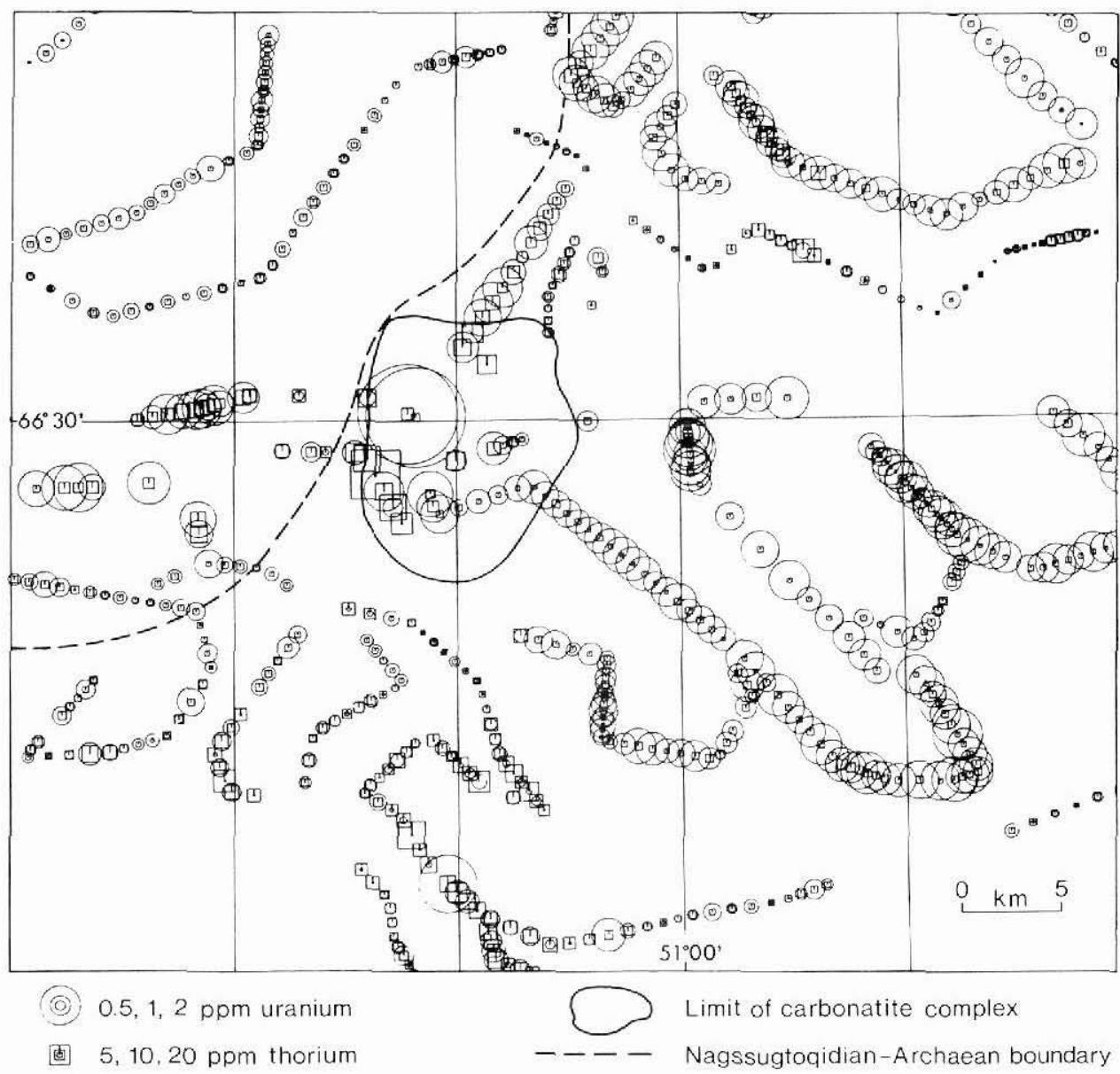

Fig. 2. Section of computer drawn airborne gamma spectrometric map (part of sheet $66 \mathrm{~V} 2$ ) showing the distribution of $\mathrm{U}$ and $\mathrm{Th}$ together with relevant geological features. Radiometric field data are represented along the flight lines, which follow topographical contours (rim flying). The carbonatite complex is recognised by anomakus values of both $\mathrm{U}$ and $T h$.

the most adequate. Automated cartographic methods were employed to provide a necessary base for data storage and presentation.

In this approach a maximum of information was obtained by intimately combining various methods of study. The value of such a strategy has recently been stressed by Cornwell (1983), and the method has been successfully applied elsewhere, for example in Tanzania by Batterham et al. (1983).

The 1975-76 regional airborne radiometry programme (Secher, 1976) resulted in a preliminary radiometric map covering a large part of central West Greenland (Secher \& Steenfe]t, 1981). Detailed follow-up radiometry on the Sarfartô complex was carried out in 1977 with the help of a small helicopter-borne scintillometer, and the area was covered with a semi- 


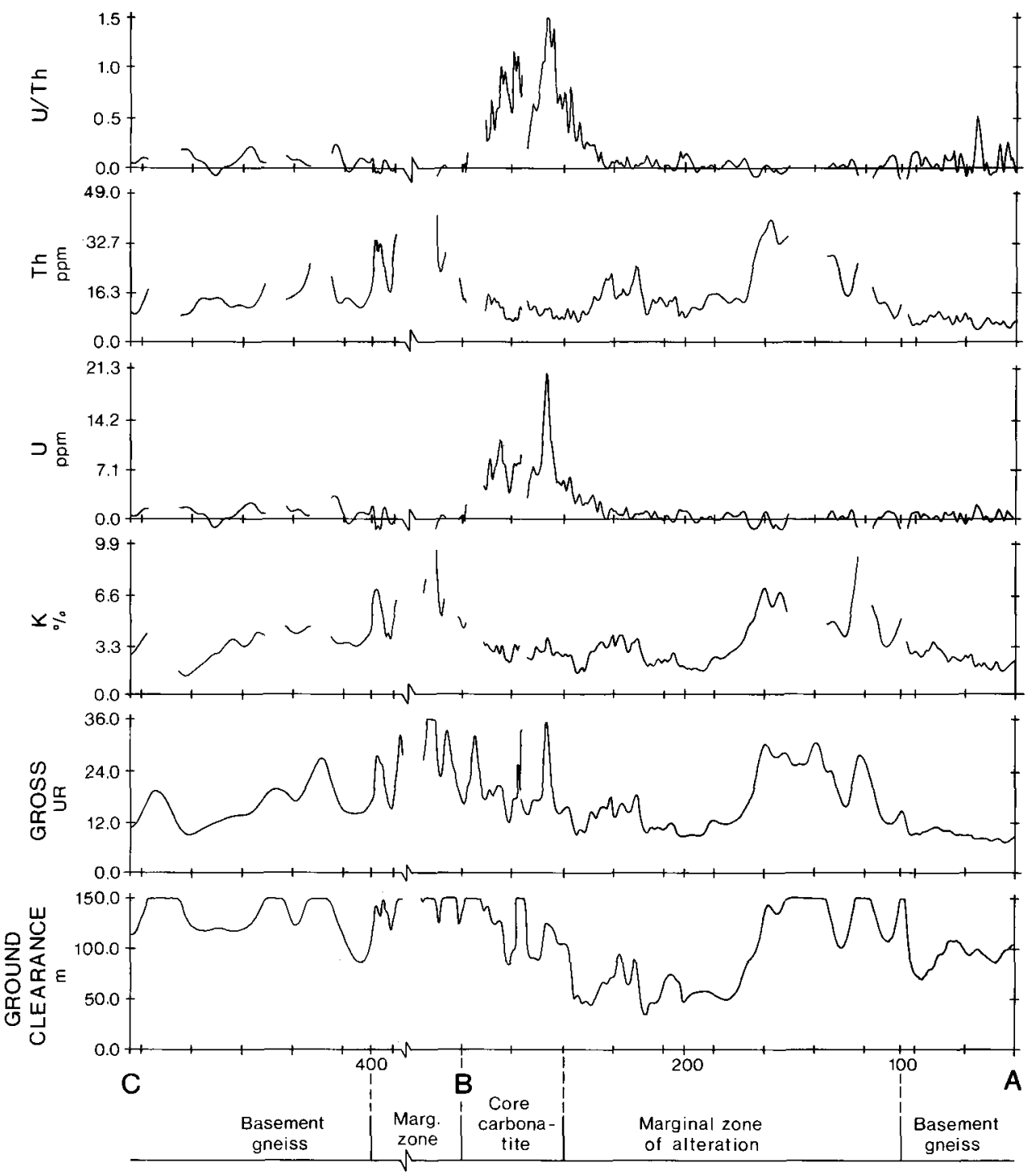

Fig. 3. Radiometric profile over the Sarfartôq carbonatite complex with geological information superimposed. The profile A-B-C is marked on the map, fig. 4 . Note that the scale is dependent on the aircraft speed and therefore not linear.

regular system of flight lines. The investigation also included detailed ground scintillometer measurements, in a regular grid, over selected localities.

Airborne geomagnetic measurements were carried out as described by Thorning (1976, $1977,1984)$, while the ground magnetometry investigation was described by Secher \& Thorning (1982). 
Exploration geochemistry, based on stream sediment and water sampling, was carried out following the practice established in East Greenland (Steenfelt \& Nielsen, 1978; Steenfelt \& Kunzendorf, 1979). First a detailed survey of the area was effectuated to obtain an impression of the outline of the carbonatite complex (Watt, 1977). This was followed by investigations on a larger scale, which formed part of GGU's regional resource mapping programme (Steenfelt \& Dam, 1982). In addition, investigation of other sampling media, e.g. heavy mineral concentrates, soils and plant leaves has been undertaken (Nielsen, 1982).

A new topographic contour map was constructed using the automated photogrammetric equipment at GGU (Secher, 1979). Aerial orthophotographs were prepared by Atlantic Air Survey, Canada, and both sets of information were merged to obtain a contoured orthophoto map of the area at the scale of 1:15 000. A geological interpretation of structural elements in the area was carried out at the same time (Secher \& Larsen, 1980).

\section{Sarfartôq investigations: stage I}

As described above, the Sarfartôq carbonatite complex was discovered during the 1975-76 regional radiometric survey. Fig. 2 gives a graphic representation of the flight lines over part of the survey area together with the measured concentrations of $U$ and Th. The outline of the Sarfartôq complex is superimposed on the radiometric map in order to demonstrate the relation between the rock types and the measurements.

The simple result of the flight line map (fig. 2) is the recognition of a number of anomalies in which either $U$ or Th predominate and attain values of more than $5 \mathrm{ppm}$ and $50 \mathrm{ppm}$, respectively. The $T h$ anomalies are typically without accompanying $U$, while the $U$ anomalies show up to equal amounts of $U$ and Th together. Within the Sarfartôq complex, $U$ anomalies are isolated and scarce, while Th anomalies occur along larger sections of the flight lines. Fig. 3 shows the continuous variation in radioelement concentrations along one of the flight lines crossing the complex. These profiles show that there is a very close correlation between $\mathrm{K}$ and Th contents, whereas $\mathrm{U}$ and Th show very poor correlation. Since the overburden along the flight lines is negligible, the measurements were considered representative for the bedrock in the area.

Based on these data a preliminary. (stage I) model of the underlying structure was set up: a large area within the basement, showing elevated radioactivity, mostly caused by Th and $\mathrm{K}$ in a perfect positive correlation, and with very low $U / T h$ ratios. Scattered $U$ anomalies with $\mathrm{U} / \mathrm{Th}$ exceeding unity are locally evident. Since low overall values of U/Th are a characteristic feature of carbonatite complexes (Heinrich, 1966), the radiometric data, combined with preliminary field and analytical evidence, were interpreted to suggest the presence of a large, circular, carbonatite intrusion.

The first geochemical field programme (Watt, 1977) supported this conclusion: the distribution of $\mathrm{Sr}$ and $\mathrm{U}$ in stream sediments showed an accumulation of high concentrations within the same limited area within which elevated radiation was detected. Sr values are here above $1000 \mathrm{ppm}$, compared to an average value of $c .400 \mathrm{ppm}$ in the adjacent basement. Similar values for $U$ are $6 \mathrm{ppm}$ and $1 \mathrm{ppm}$, respectively.

The geomagnetic measurements clearly supported the view of a ring structure. The magnetic picture, as described by Secher \& Thorning (1982), consists of a pronounced ovalshaped positive anomaly of just over $200 \mathrm{nT}$, surrounded by a marginal low, representing almost non-magnetic rocks. The positive anomaly coincides with magnetite-bearing rocks in 


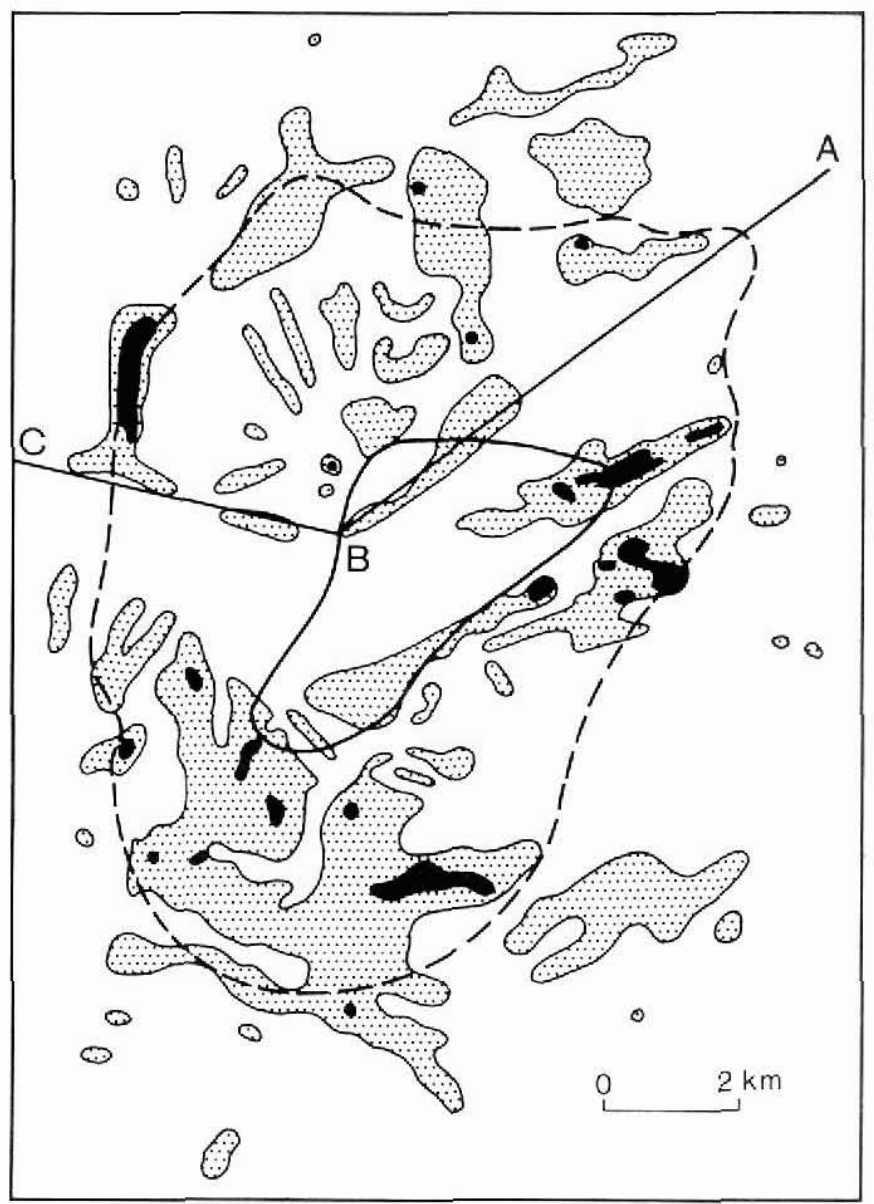

Fig. 4. Radiometric map of the Sarfartôq carbonatite complex with iso-rad contours, based on helicopterborne scintillometry.
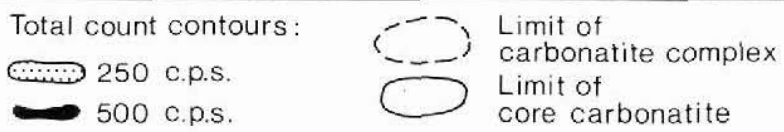

the central part of the structure. The magnetic low is correlated with rocks where hematite has replaced a majority of the minerals with high magnetic susceptibility.

\section{Sarfartôq investigations: stage II}

After confirmation of the presence of a carbonatite intrusion at Sarfartôq, detailed mapping was a logical next step. This field work began in 1977. Different types of carbonatitic rocks were recognised, and the outline of the complex was roughly established (Secher \& Larsen, 1978). Small scintillometers, both helicopter and hand-borne, were of invaluable help during this phase of the investigation. Fig. 4 shows the gross channel radiometric map of the complex, made by a helicopter survey. The outline of the complex is clearly displayed, 
Table 1. Chemical analyses of Sarfartôq carbonatites (wt\%)

\begin{tabular}{lrrrr}
\hline & \multicolumn{1}{c}{1} & 2 & \multicolumn{1}{c}{3} & \multicolumn{1}{c}{4} \\
\hline $\mathrm{SiO}_{2}$ & $0.52-3.27$ & 2.05 & $5.08-31.07$ & 17.43 \\
$\mathrm{TiO}_{2}$ & $0.01-0.22$ & 0.08 & $0.11-0.60$ & 0.31 \\
$\mathrm{Al}_{2} \mathrm{O}_{3}$ & $0.02-0.31$ & 0.13 & $0.78-7.23$ & 3.18 \\
$\mathrm{Fe}_{2} \mathrm{O}_{3}$ & $0.39-5.06$ & 1.86 & $0.85-5.07$ & 2.53 \\
$\mathrm{FeO}$ & $3.66-6.42$ & 4.68 & $3.06-7.87$ & 4.70 \\
$\mathrm{MnO}$ & $0.30-0.62$ & 0.41 & $0.22-0.49$ & 0.36 \\
$\mathrm{MgO}$ & $14.35-16.78$ & 15.53 & $8.24-15.54$ & 11.92 \\
$\mathrm{CaO}$ & $27.53-30.24$ & 28.97 & $14.96-26.86$ & 20.81 \\
$\mathrm{Na}{ }_{2} \mathrm{O}$ & $0.03-0.57$ & 0.26 & $0.03-1.54$ & 0.76 \\
$\mathrm{~K}_{2} \mathrm{O}$ & $0.02-0.15$ & 0.08 & $0.59-5.11$ & 2.35 \\
$\mathrm{P}_{2} \mathrm{O}_{5}$ & $2.30-5.10$ & 3.59 & $0.07-1.74$ & 0.86 \\
volatile & $36.23-42.41$ & 39.30 & $21.37-39.98$ & 31.80 \\
& $96.30-97.97$ & & $96.41-98.13$ & \\
\hline
\end{tabular}

\begin{abstract}
Analyses carried out at GGU's chemical laboratory. Method: XRF analysis on fused glass discs except for $\mathrm{MgO}$ and $\mathrm{Na}_{2} \mathrm{O}$ which are by AAS.

(1) Range of rauhaugites (15), core zone; (2) Average of 1; (3) Range of beforsite dykes (4), marginal zone; (4) Average of 3.
\end{abstract}

and within the complex, regions with different radiation levels appear, as well as a number of very 'hot' areas.

Based on this new information the stage II model for the structure of the Sarfartô complex was developed: an oval structure with increasing radiation outwards from the centre. 'Hot' areas were found all over the complex but mainly located in the outer rim. Intrusive carbonatites were found to be predominant in the central parts, the 'core zone', which is surrounded by different rocks formed by alteration of the basement. The core zone was subdivided into an 'inner' and 'outer' core with, respectively, more and less than $50 \%$ carbonatite. The area of alteration constitutes a fenite zone adjacent to the core, and a marginal zone of metasomatic and cataclastic rocks, rimming the complex. Discordant carbonatitic dyke rocks were found all over the complex although most frequently in the marginal zone.

A geochemical programme was carried out to investigate $\mathrm{Zn}, \mathrm{Pb}$ and $\mathrm{Cu}$ mineralisation related to the complex (Nielsen, 1982). $\mathrm{Zn}$ and $\mathrm{Pb}$ were found to be positively correlated, deposited together with baryte, sphalerite and galena in the zones enriched in Th and REE. Maximum contents of $\mathrm{Zn}$ and $\mathrm{Pb}$ are $1.5 \%$ and $0.1 \%$, respectively. $\mathrm{Cu}$ is slightly enriched in all rock types of the complex $(30-40 \mathrm{ppm})$, but chalcopyrite is only observed rarely in late sulphide-calcite veins. Stream sediments clearly outlined the $\mathrm{Zn}-\mathrm{Pb}$-mineralised areas, while the use of soil and plant leaves was only applicable in the detailed mapping of the mineralisation.

Continued work in the Sarfartôq complex has resulted in much detailed geochemical and mineralogical information. The major carbonatites of the core (rauhaugite and sövite) are characterised by very low contents of $\mathrm{SiO}_{2}, \mathrm{Al}_{2} \mathrm{O}_{3}$ and $\mathrm{K}_{2} \mathrm{O}$, (Table 1) compared to similar rocks from other complexes. Apparently only one, rather uniform phase of rauhaugite is present, while three successive phases of sövitic carbonatite can be distinguished, according to the variation of the $\mathrm{P}_{2} \mathrm{O}_{5}$ content (from 0.1 to $12.5 \mathrm{wt} \%$ ) versus the $\mathrm{CaO} / \mathrm{MgO}$ ratio (from 
Table 2. Minerals found in the Sarfartôq carbonatite complex

\begin{tabular}{|c|c|c|c|c|}
\hline & $\begin{array}{l}\text { Core } \\
\text { zone }\end{array}$ & $\begin{array}{l}\text { Marginal } \\
\text { zone }\end{array}$ & $\begin{array}{l}\text { Late } \\
\text { mineralised } \\
\text { veins }\end{array}$ & $\begin{array}{l}\text { Surface } \\
\text { coatings }\end{array}$ \\
\hline $\begin{array}{l}\text { ELEMENTS } \\
\text { Graphite }\end{array}$ & 0 & & & \\
\hline $\begin{array}{l}\text { SULPHIDES } \\
\text { Pyrite } \\
\text { Marcasite } \\
\text { Pyrrhotite } \\
\text { Sphalerite } \\
\text { Galena } \\
\text { Chalcopyrite }\end{array}$ & $\begin{array}{l}+ \\
\star\end{array}$ & $\begin{array}{l}+ \\
0 \\
0 \\
0 \\
0\end{array}$ & $\stackrel{0}{0}$ & \\
\hline $\begin{array}{l}\text { OXIDES } \\
\text { Magnetite } \\
\text { Illmenite } \\
\text { Hematite } \\
\text { Nb-rutile } \\
\text { Pyrochlore }\end{array}$ & $\begin{array}{l}\stackrel{\bullet}{+} \\
\stackrel{0}{0} \\
\vdots \\
\star\end{array}$ & $\begin{array}{l}+ \\
0 \\
\stackrel{+}{+} \\
+\end{array}$ & 0 & \\
\hline $\begin{array}{l}\text { HYDROXIDES } \\
\text { Goethite }\end{array}$ & 0 & 0 & 0 & 0 \\
\hline $\begin{array}{c}\text { HALIDES } \\
\text { Fluorite }\end{array}$ & & 0 & $\star$ & \\
\hline $\begin{array}{l}\text { CARBONATES } \\
\text { Calcite } \\
\text { Dolomite-ankerite } \\
\text { Siderite } \\
\text { Monohydrocalcite }\end{array}$ & $\stackrel{\star}{\bullet}$ & 8 & $\stackrel{\bullet}{\star}$ & - \\
\hline $\begin{array}{l}\text { SULPHATES } \\
\text { Baryte } \\
\text { Hexahydrite } \\
\text { Gypsum }\end{array}$ & & + & $\star$ & 8 \\
\hline $\begin{array}{l}\text { PHOSPHATES } \\
\text { Apatite } \\
\text { Unidentified }\end{array}$ & 0 & $\stackrel{+}{\circ}$ & & \\
\hline $\begin{array}{l}\text { SILICATES } \\
\text { Zircon } \\
\text { Alkali pyroxene } \\
\text { Alkali amphibole } \\
\text { Phlogopite-biotite } \\
\text { Chlorite } \\
\text { Taeniolite? } \\
\text { Quartz } \\
\text { Chalcedony } \\
\text { K-feldspar } \\
\text { Albite } \\
\text { Zeolite }\end{array}$ & $\stackrel{+}{\star}$ & $\begin{array}{l}+ \\
\star \\
8 \\
0 \\
+ \\
0 \\
+ \\
0 \\
0\end{array}$ & $\stackrel{+}{\mathrm{O}}$ & \\
\hline
\end{tabular}

Abundant

+ Widespread accessory

* Locally concentrated

Rare 


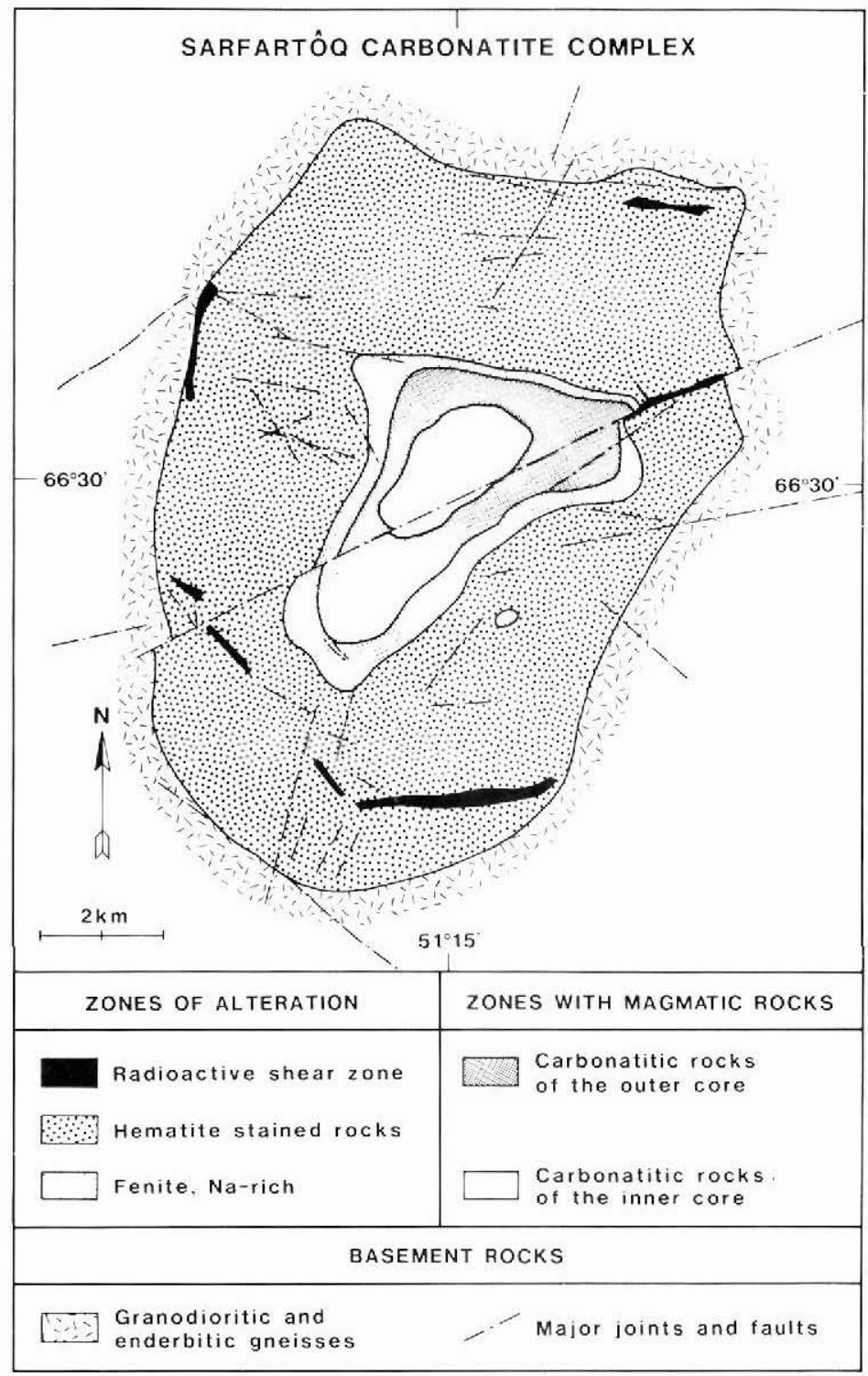

Fig. 5. Geological map of the Sarfartôq carbonatite complex, based on a combination of survey methods as described in this paper.

3 to 8). The dyke carbonatite is Fe-rich beforsite with a composition heavily influenced by wall rock contamination (Table 1).

Mineralogically, a suite of typical carbonatite species was recognised: dolomite, calcite, apatite, phlogopite, magnetite, richterite-arfvedsonite, zircon and pyrochlore. Over 30 different minerals (Table 2) are known from the complex. A characteristic feature of the Sar- 
fartôq carbonatites is the absence of silicate minerals like olivine, diopside and sphene (Secher \& Larsen, 1980). However, results from an examination of the REE content in the carbonatites support the view that the Sarfartôq rocks were developed as classical carbonatites. One exception is the high REE fractionation in the Sarfartôq carbonatites with an average $\mathrm{La} / \mathrm{Yb}$ value of around 190 . This value is ascribed to the minimal exchange between the primary carbonatite magma and the adjacent silicate rocks, as demonstrated by the paucity in the complex of intrusive silicate rocks (Secher, 1980; Secher \& Larsen, 1980).

Testing of the Sarfartôq stage II model resulted in the map reproduced in Secher \& Larsen (1980). Fig. 5 shows a revised geological map, which includes information from detailed geomagnetic work and supplementary field data. The ground magnetic survey (Secher \& Thorning, 1982) gave a precise outline of the intrusive carbonatitic inner core of $c .3 \mathrm{~km}^{2}$. It was found that a large part of this core consists of a very weakly magnetic rock type, probably pure sövite, and the occurrence of a major transcurrent fault, suggested by structural measurements, was verified by the ground magnetic data. Geological investigations carried out simultaneously established the presence of a swarm of kimberlite cone sheets, up to $20 \mathrm{~km}$ away centred on the complex, as a related part of the igneous history (Larsen, 1980).

The resulting model envisages a multi-phase carbonatite intrusion, a little atypical because of the absence of intrusive silicate rocks, which has created a zone of Na-fenite at its contact with the gneissic basement. An unusually large concentric zone of hydrothermal alteration terminates the igneous activity outwards. This zone is chemically characterised by an enhancement of potassium in the basement gneisses by a factor of 1.5-3. This is closely correlated with an increased thorium content, 3-10 times the gneiss background. Furthermore, this $75 \mathrm{~km}^{2}$ zone is strongly red-stained due to the widespread occurrence of hematite. Areas of anomalous radiation are all confined to this marginal zone and are caused by two successive groups of radioactive mineralisation. The earliest to be deposited is made up of at least three stages of monomineralic pyrochlore accumulation related to older cataclastic structures. The pyrochlore carries up to $1 \mathrm{wt} \% \mathrm{U}$ and only traces of Th. REE are important minor elements in the pyrochlore. The second group is more frequent and is located in elongated zones related to syn- or post-emplacement fault structures. It is caused by unidentified Th-REE minerals, also enriched in $\mathrm{Zn}$ and $\mathrm{Ba}$, and is contemporaneous with the formation of the marginal zone proper.

At the close of the carbonatite activity, the hydrothermal influence apparently reached the surface, and hot circulating water locally dissolved the carbonatite. Several localities within the complex show small cavities (up to 10 litres in volume) hiding fossil stalactites, partly embedded in hydrothermal minerals: coarse crystals of calcite, barite, quartz and subordinate chalcopyrite. Other cavities are filled with siliceous and calcareous sinter material, resembling geyserite and carbonate tufa. REE analyses show evidence of waning igneous activity, i.e. very low $\mathrm{La} / \mathrm{Yb}$ ratio (around 6) and low total REE content (50 ppm) (Secher, 1980; Nielsen, 1982).

Possible fossils have been observed in some of these cavities: annelid-like organisms of assumed Cambrian age (Peel \& Secher, 1979). The exact morphology of these organisms, more or less living in hydrothermal solutions, is partially obliterated by the crystallisation of the cavity-filling minerals. 


\section{Economic geology}

Although only tentative calculations have been made, the resource potential of the Sarfartôq carbonatite complex is thought to be large. Phosphorus, niobium and REE occur in possibly economic concentrations.

The phosphorus content is located only in primary apatite within the rauhaugite (the outer core), which shows a range of $\mathrm{P}_{2} \mathrm{O}_{5}$ grade from 0.5 to $8.0 \mathrm{wt} \%$ with $3.5 \mathrm{wt} \%$ as an average. Unlike the rauhaugite each of the three sövite phases varies only a few percent in $\mathrm{P}_{2} \mathrm{O}_{5}$ content. Although values up to $12.0 \mathrm{wt} \%$ are found, the only sövite phase of any extent (the inner core) has a constantly low $\mathrm{P}_{2} \mathrm{O}_{5}$ value of around $1 \mathrm{wt} \%$. Based on this a rough conservative estimate to depths of 100 and $200 \mathrm{~m}$ results in 0.5 to $1 \times 10^{9}$ tons, respectively, of rauhaugite with an average grade of $3.5 \mathrm{wt} \% \mathrm{P}_{2} \mathrm{O}_{5}$ (Secher in press).

Niobium is found almost exclusively in the zones of pyrochlore accumulation within the marginal zone. The $\mathrm{Nb}$ content in these zones is notable and varies from 5 to $40 \%$ according to the amount of siliceous matrix. The spatial distribution of the pyrochlore is rather scattered and only one locality is found to be of probable economic interest. A tentative calculation to a depth of $50 \mathrm{~m}$ at this locality results in $0.1 \times 10^{6}$ tons of ore with an average grade of $15 \mathrm{wt} \% \mathrm{Nb}_{2} \mathrm{O}_{5}$. Additionally the pyrochlore carries up to $1 \% \mathrm{U}, 1.6 \%$ REE (La$\mathrm{Nd}$ ) and $0.5 \% \mathrm{Ta}$.

Rare earth elements are found in increased contents at several localities within the complex (see also above). Radioactive shear zones in the marginal part of the complex in particular show noteworthy concentrations of LREE (up to $0.5 \%$ ), especially Eu (up to 236 ppm). However, such LREE carrying rocks are only observed at a few localities and have a limited extent. Maximum contents of associated $\mathrm{Zn}$, Th and $\mathrm{Ba}$ are $11.5 \%, 0.2 \%$ and $0.6 \%$, respectively.

Hydrothermal veins consisting of dolomite and REE-carbonate are found to carry up to $7 \%$ REE, mainly La and Ce. These veins are observed scattered throughout the complex, most frequently within the marginal zone. They are $5-20 \mathrm{~cm}$ in width and only rarely up to $0.5 \mathrm{~m}$. The REE veins are not considered to be of direct economic interest.

No exploration license has been granted within the area, which is covered by a local preservation order.

\section{Future work}

The main mapping stage of the complex is now completed. Part of the data gathered are still in the process of evaluation. In continuation of other laboratory investigations, a study of the isotopic compositions of $\mathrm{Sr}, \mathrm{O}$ and $\mathrm{C}$ in the complex has been initiated. A detailed study of the mineral chemistry of the pyrochlore mineralisation is in progress.

\section{Summary}

The Sarfartôq carbonatite complex was discovered during a regional airborne radiometric survey. The investigation of the complex was carried out by a combination of geophysical, geochemical and geological methods in which radiometry played a major role. The complex has an age of $c .600 \mathrm{Ma}$ and was emplaced in the border zone between the Archaean craton 
and the Nagssugtoqidian mobile belt just south of Søndre Strømfjord. Carbonatitic magma was intruded in at least two major stages of activity. In the first stage a steeply dipping conical body of concentric sheets of sövite and rauhaugite was formed while in the later stages several batches of magma were emplaced into the surrounding marginal shock zone as tangential and radial dykes and agglomerates. Hydrothermal activity gave rise to several phases of mineralisation in veins and shear zones. The accompanying fenitisation was of the $\mathrm{Na}$ type. The whole complex covers $c .100 \mathrm{~km}^{2}$, of which $10 \mathrm{~km}^{2}$ consists of intrusive carbonatite.

The history of exploration of the Sarfartôq carbonatite complex stresses the importance of combining several methods in the survey procedure.

Acknowledgements. The cooperation with Ris $\emptyset$ National Laboratory, Nuclear Geophysics Group, during the work, both in the field and in the laboratory, is greatly appreciated. Invaluable support was received from many colleagues at the Survey and at the University of Copenhagen. Part of the analytical work was funded by a grant from the Natural Science Research Council (SNF) under contracts No. 119380 and No. 11-0165.

\section{References}

Batterham, P. M., Bullock, S. J. \& Hopgood, D. N. 1983: Tanzania: integrated interpretation of aeromagnetic and radiometric maps for mineral exploration. Trans. Inst. Min. Metall. 92 B, 83-92.

Christiansen, E. M. 1973: Hugin, flybåret gamma-spektrometer. Int. Risø report, 14 pp.

Cornwell, J. D. 1983: Geophysical methods in mineral exploration. Trans. Inst. Min. Metall. 92 B, 8082.

Emeleus, C. H. 1964: The Grønnedal-Ika alkaline complex, South Greenland. Meddr Grønland 172 (3), $75 \mathrm{pp}$.

Escher, A. \& Watterson, J. 1973: Kimberlites and associated rocks in the Holsteinsborg - Søndre Strømfjord region, central West Greenland. Rapp. Grønlands geol. Unders. 55, 26-27.

Heinrich, E. W. 1966: The geology of carbonatites. 555 pp. Chicago: Rand, McNally \& Co.

Knudsen, C. 1985: Investigations of the Qaqarssuk carbonatite complex, southern West Greenland. Rapp. Grønlands geol. Unders. 125, 34-40.

Knudsen, C. \& Secher, K. 1984: Apatite mineralisation in carbonatite and ultramafic intrusions in Greenland. Interim report $1, E E C, R \& D$ programme: Raw materials. $30 \mathrm{pp}$.

Kunzendorf, H. \& Secher, K. (in press): Dispersion of niobium and phosphorus in soil overlying the Qaqarssuk carbonatite complex, southern West Greenland. J. Geochem. Exploration.

Larsen, L. M. 1980: Lamprophyric and kimberlitic dykes associated with the Sarfartôq carbonatite complex, southern West Greenland. Rapp. Grønlands geol. Unders. 100, 65-69.

Larsen, L. M. \& Pedersen, A. K. 1982: A minor carbonatite occurrence in southern West Greenland: the Tupertalik intrusion. Rapp. Grønlands geol. Unders. 110, 38-43.

Larsen, L. M., Rex, D. C. \& Secher, K. 1983: The age of carbonatites, kimberlites and lamprophyres from southern West Greenland: Recurrent alkaline magmatism during 2500 million years. Lithos. 16, 215-221.

Nielsen, B. L. 1976: Economic minerals. In Escher, A. \& Watt, W. S. (edit.) Geology of Greenland, 460-487. Copenhagen: Geol. Surv. Greenland.

Nielsen, L. W. 1982: Geokemiske og malmgeologiske undersøgelser i og omkring karbonatitkomplekset Sarfartôq, Vestgrønland, med særlig henblik på Cu-Pb-Zn-mineraliseringer. Unpublished dissertation, Univ. Copenhagen, $167 \mathrm{pp}$. 
Peel, J. S. \& Secher, K. 1979: A second fossil occurrence from the Precambrian Shield of southern West Greenland. Rapp. Gronlands geol. Unders. 91, 99-104.

Secher, K. 1976: Airborne radiometric survey between $66^{\circ}$ and $69^{\circ} \mathrm{N}$, southern and central West Greenland. Rapp. Grønlands geol. Unders. 80, 65-67.

Secher, K. 1977: Airborne radiometric survey between $63^{\circ}$ and $66^{\circ}$ N, southern West Greenland. Rapp. Grønlands geol. Unders. 85, 49-50.

Secher, K. 1979: A new topographic and geological map of an area south-west of Søndre Strømfjord. Meddr Inst. Landmål. Fotogram. 10, 182-185.

Secher, K. 1980: Indhold af lanthanider i karbonatitbjergarter fra Sarfartôq karbonatitkomplekset, centrale Vestgrønland, bestemt ved instrumentel neutronaktiveringsanalyse (INAA). Internal GGU report, $13 \mathrm{pp}$.

Secher, K. in press: Phosphate resources in the Sarfartôq carbonatite complex, southern West Greenland. In Sheldon, R. P. \& Notholt, A. J. G. (edit.) Phosphate deposits of the world, 2. Cambridge University Press.

Secher, K. \& Larsen, L. M. 1978: A new Phanerozoic carbonatite complex in southern West Greenland. Rapp. Grønlands geol. Unders. 90, 46-50.

Secher, K. \& Larsen, L. M. 1980: Geology and mineralogy of the Sarfartôq carbonatite complex, southern West Greenland. Lithos 13, 199-212.

Secher, K. \& Steenfelt, A. 1981: A preliminary radiometric map of central West Greenland. Internal GGU report, 3 pp.

Secher, K. \& Thorning, L. 1982: Detailed ground magnetic survey in the Sarfartôq carbonatite complex, southern West Greenland. Rapp. Grønlands geol. Unders. 110, 32-38.

Steenfelt, A. \& Dam, E. 1982: Reconnaissance study of uranium and fluorine contents of stream and lake waters, West Greenland. Rapp. Grønlands geol. Unders. 110, 26-32.

Steenfelt, A. \& Kunzendorf, H. 1979: Geochemical methods in uranium exploration in northern East Greenland. In Watterson, J. R. \& Theobald, P. K. (edit.) Geochemical Exploration 1978, 429-442. Association of Exploration Geochemists.

Steenfelt, A. \& Nielsen, B. L. 1978: Field work in uranium geology and prospecting, northern East Greenland. Rapp. Gronlands geol. Unders. 90, 89-94.

Stewart, J. W. 1970: Precambrian alkaline-ultramafic/carbonatite volcanism of Qagssiarssuk, South Greenland. Bull. Grønlands geol. Unders. 84, $70 \mathrm{pp}$.

Thorning, L. 1976: Aeromagnetic survey in southern and central West Greenland between $63^{\circ}$ and $71^{\circ}$ N. Rapp. Grønlands geol. Unders. 80, 61-65.

Thorning, L. 1977: Continuation of the aeromagnetic surveys in southern and central West Greenland between $64^{\circ}$ and $72^{\circ} \mathrm{N}$. Rapp. Gronlands geol. Unders. 85, 34-37.

Thorning, L. 1984: Aeromagnetic maps of parts of southern and central West Greenland: acquisition, compilation and general analysis of data. Rapp. Grønlands geol. Unders. 122, $36 \mathrm{pp}$.

Watt, M. 1977: Geokemisk prøveindsamling i Nordre Strømfjord og 'Sarfartôq', centrale Vestgrønland. Internal GGU report, $12 \mathrm{pp}$. 